\title{
ANALISIS KUALITAS TERJEMAHAN ARTIKEL MEDIA OLEH MAHASISWA PRODI D-3 BAHASA INGGRIS POLITEKNIK
}

\author{
Alief Sutantohadi, Politeknik Negeri Madiun \\ alief@pnm.ac.id
}

\begin{abstract}
This qualitative-inductive research is conducted to identify and describe the translation technics used by the students of D-3 programe of English Department of State Polytechnics of Madiun in translating the articles from The Jakarta Post daily newspaper. This research will also analise the the quality of translation result and its relationship with the students' competence in translation. The data in this research will be analised by using Content Analisis from Spradley. By using this technic, the data will be analised through some steps as domain analysis, taxonomic analysis, componential analysis and taking the cultural findings. The result of the quality assesment of translation shows that the students' competence in translation is adequate. This achievement is based on the result of assesment on the accuracy and the acceptability of the translation. The assesment on the accuracy of the translation shows from total 105 data were translated accurately for 66 data $(62.86 \%)$ and then 21 data $(20 \%)$ were translated less accurately and the rest for 18 data $(17.14 \%)$ were translated inacurately. The assesment result on acceptability of the translation shows from total 105 data were translated acceptable for 73 data (69.52\%) and then 20 data (19.05\%) were translated less acceptable and the rest for 12 data $(11.43 \%)$ were translated unacceptable.
\end{abstract}

Key Words : the quality of translation, translation technique. 


\begin{abstract}
ABSTRAK
Penelitian induktif-kualitatif ini bertujuan untuk mengidentifikasi dan mendeskripsikan teknik penerjemahan yang digunakan mahasiswa Prodi D-3 Bahasa Inggris Politeknik Negeri Madiun dalam penerjemahan artikel dari sumber koran berbahasa Inggris The Jakarta Post. Penelitian juga bertujuan untuk menganalisa kualitas hasil terjemahan dan hubungan antara kualitas hasil terjemahan dengan kompetensi penerjemahan para mahasiswa. Teknik analisis data yang digunakan dalam penelitian ini mengacu pada Content Analysis dari Spradley. Dengan menggunakan acuan ini, data dinalisis melalui serangkaian tahapan, dimulai dari analisis domain, taksonomi, komponensial sampai temuan. Dari analisis kualitas terjemahan, yang memberikan penilaian terhadap tingkat keakuratan dan keberterimaan, bisa disimpulkan bahwa kemampuan/kompetensi penerjemahan mahasiswa sudah cukup baik. Hal itu didasarkan pada hasil penilaian terhadap aspek keakuratan dan keberterimaan. Penilaian menunjukkan bahwa dalam aspek keakuratan, dari 105 data yang diteliti didapat 66 (62.86\%) data dengan terjemahan yang akurat, 21 (20\%) data diterjemahkan dengan kurang akurat, dan 18 (17.14\%) data diterjemahkan tidak akurat. Dalam aspek keberterimaan, dari 105 data yang diteliti didapat $73(69.52 \%)$ data dengan terjemahan yang berterima, 20 (19.05\%) data diterjemahkan dengan kurang berterima, dan 12 (11.43\%) data diterjemahkan tidak berterima.
\end{abstract}

Kata Kunci : kualitas terjemahan, teknik terjemahan 


\section{PENDAHULUAN}

Sebagaimana kita semua memaklumi bahwa tahun 2015 merupakan sebuah momentum yang penting bagi kerjasama antar negara khususnya negara Indonesia dengan beberapa negara ASEAN lainnya dengan dimulainya kerjasama Masyarakat Ekonomi Asean (Asean Economic Community). Oleh karena itu diperlukan kemampuan dan keterampilan berkomunikasi sebagai salah satu perangkat wajib yang harus dimiliki setiap bangsa dalam membina hubungan kerjasama global antarbangsa. Para mahasiswa hendaknya membekali diri dengan ketrampilan berbahasa agar bisa berkompetisi dan mendapatkan peluang berkarir yang baik.

Maka penelitian ini melakukan kajian terhadap kemampuan mahasiswa dalam menerjemahkan teks bahasa Inggris kedalam bahasa Indonesia. Dalam penelitian ini, penulis memberikan batasan agar penelitian terfokus pada permasalahan yang akan diteliti yaitu mengkaji hasil terjemahan artikel yang diambil dari koran harian berbahasa Inggris 'The Jakarta Post' oleh mahasiswa Politeknik Negeri Madiun. Kajian yang dimaksud meliputi kualitas hasil terjemahan yang mencakup dua aspek penilaian yaitu aspek keakuratan dan keberterimaan. Dalam penelitian ini satuan lingual yang dikaji adalah tindak tutur ekspresif tataran kata, frasa, klausa dan kalimat.

\section{PERMASALAHAN}

Sesuai dengan judul, penulis merumuskan beberapa permasalahan yang akan dikaji. Permasalahan tersebut sebagai berikut:

1. Teknik penerjemahan apa yang digunakan?

2. Bagaimana kualitas keakuratan dan keberterimaan hasil terjemahan ?

3. Bagaimana hubungan kualitas hasil terjemahan terhadap kompetensi penerjemahan para mahasiswa?

\section{TUJUAN PENELITIAN}

Penelitian ini bertujuan untuk;

1. Mengidentifikasi dan mendeskripsikan teknik penerjemahan yang digunakan dalam penerjemahan artikel The Jakarta Post.

2. Mengetahui kualitas hasil terjemahan artikel The Jakarta Post oleh mahasiswa Prodi Bahasa Inggris Politeknik Negeri Madiun. 
3. Mengetahui hubungan antara kualitas hasil terjemahan dengan kompetensi penerjemahan para mahasiswa.

\section{TINJAUAN PUSTAKA}

\section{Penerjemahan dan Kualitas terjemahan}

Menerjemahkan sebuah teks dari bahasa sumber ke dalam bahasa sasaran agar menghasilkan hasil terjemahan yang baik dan berkualitas secara gramatikal dan natural, melibatkan banyak faktor yang secara langsung atau tidak mempengaruhi hasil terjemahan.

Larson (1984: 3) says that translation consist of translating the meaning of the source language into the receptor language. This is done by going from the form of the first language to the form of a second language by way of semantic structure. It is meaning which is being transferred and be held constant. Only the form changes.

Menurut pendapat Larson, translasi meliputi kegiatan menerjemahkan makna dari bahasa sumber ke dalam bahasa penerima, dari bentuk bahasa pertama menuju bentuk bahasa kedua dengan menggunakan struktur semantik. Dalam hal ini maknalah yang dialihkan dan harus di pegang teguh, hanya bentuknya yang berubah.

Kualitas hasil terjemahan ditentukan oleh tiga aspek yaitu keakuratan, keberterimaan, dan keterbacaan. Tentu saja, hasil terjemahan yang terbaik adalah hasil terjemahan yang memiliki tingkat keakuratan, keberterimaan, dan keterbacaan yang tinggi. Akan tetapi, dengan berbagai pertimbangan terkadang dalam praktiknya sulit untuk menghasilkan terjemahan yang sempurna. Hal tersebut disebabkan karena penerjemah sering dihadapkan dengan pilihan untuk lebih mementingkan suatu aspek dan agak mengorbankan aspek yang lain.

Aspek pertama adalah aspek keakuratan yang berkait dengan kesepadanan makna antara bahasa sumber (BSu) dan bahasa sasaran (BSa). Pesan yang diterjemahkan harus tersampaikan secara akurat dan memiliki makna yang sepadan. Kesepadanan makna yang dimaksud bukan sekedar dari segi bentuk, tetapi juga pesan, gagasan dan ide. Aspek keakuratan merupakan prinsip dasar dalam penerjemahan, sehingga harus menjadi fokus utama seorang penerjemah. Apabila tingkat keakuratan suatu hasil 
terjemahan sangat rendah, maka perlu dipertanyakan apakah terjemahan tersebut termasuk hasil terjemahan yang berkualitas atau bukan.

Aspek kedua adalah aspek keberterimaan yang juga merupakan faktor penting yang menentukan kualitas hasil terjemahan. Aspek keberterimaan merupakan derajat kewajaran suatu teks hasil terjemahan terhadap norma, budaya dan kaidah BSa. Dalam usaha untuk mencapai hasil terjemahan dengan tingkat keberterimaan yang tinggi seorang penerjemah harus memiliki kompetensi yang baik terhadap bahasa dan budaya BSa agar mampu menyesuaikan antara tata bahasa dan norma budaya BSu dengan tata bahasa dan norma budaya BSa.

\section{Penelitian sebelumnya dengan media koran The Jakarta Post}

Banyak penelitian yang telah dilakukan dalam bidang linguistik yang beberapa diantaranya menggunakan media koran berbahasa Inggris The Jakarta Post sebagai sumber data yang diteliti.

Yohansyah (2011) melakukan penelitian tentang proses morfologis kata yang bersufiks "-er", serta tentang perubahan kelas kata, dan proses penyesuaian huruf pada kata yang bersufiks “-er". Dari penelitian yang telah dilakukanya disimpulkan bahwa perubahan kategori sintaksis pada kata yang bersufiks "-er" dapat berupa infleksional ataupun derivasional; sufiks "-er" dapat melekat pada kategori sintaksis nomina, verba, dan ajektifa. Proses sufiksasi "-er" tidak hanya menambahkan sufiks "-er" begitu saja, ada pengurangan atau penambahan huruf yang terdapat pada kata bersufiks "-er".

Dwiana (2013) meneliti penggunaan participle seperti tampak pada judul-judul artikel di koran The Jakarta Post. Hasil dari penelitianya adalah lima pola penggunaan present participle, enam tipe penggunaan past participle, makna dibaliknya, serta frekuensi penggunaannya.

Rofi'ah (2014) meneliti penggunaan pronomina di The Jakarta Post dan Jakarta Globe. Hasil dari penelitian ini menunjukkan bahwa frekuensi pronomina di The Jakarta Post lebih sedikit dari pada di Jakarta Globe. Kedua surat kabar tersebut memiliki lima strategi yang sama dalam menggunakan pronomina. Selain itu, The Jakarta Post mempunyai tiga strategi pronomina yang berbeda, dan Jakarta Globe mempunyai dua lainnya. Hasil-hasil ini menunjukkan bahwa kedua surat kabar tersebut memiliki persamaan dan perbedaan dalam menggunakan pronomina. 
Novena (2015) melakukan penelitian untuk 1) menganalisis jenisjenis ambiguitas leksikal yang terdapat pada artikel koran The Jakarta Post dan 2) mengetahui penyebab terjadinya ambiguitas leksikal pada poin 1 di atas. Sedangkan hasilnya menunjukan bahwa 1) terdapat dua jenis ambiguitas leksikal yang ditemukan dalam penelitian ini yaitu ambiguitas lokal (local ambiguity) sebanyak 30 data $(85,7 \%)$ dan ambiguitas global (global ambiguity) sebanyak 5 data (14,3\%). 2). Penyebab terjadinya ambiguitas leksikal lokal (local ambiguity) yaitu polisemi dan homonimi sedangkan penyebab terjadinya ambiguitas leksikal global (global ambiguity) adalah struktur kalimat yang digunakan dalam artikel koran The Jakarta Post.

Penelitian yang kami lakukan berbeda dengan penelitian-penelitian yang dilakukan sebelumnya karena pada penelitian ini akan meneliti artikel dari sumber koran The Jakarta Post dari aspek penerjemahan dan kualitas hasil terjemahan.

\section{METODE PENELITIAN}

\section{Desain Penelitian}

Penelitian ini merupakan penelitian induktif-kualitatif. Penelitian ini termasuk penelitian induktif karena penelitian ini diawali dangan mengumpulkan data, mengembangkan teori atau dugaan, menguji validitas dan selanjutnya menemukan jawaban dari permasalahan sebagai simpulan terakhir. Penelitian ini juga termasuk kualitatif karena data utama yang diteliti berupa kalimat bukan angka- angka (numeric). Sedangkan perhitungan statistik dalam penelitian ini hanyalah sebagai alat bantu menemukan tingkat keakuratan, keberterimaan dan keterbacaan terjemahan.

Pendekatan yang digunakan dalam penelitian ini adalah pendekatan penerjemahan. Teori yang akan digunakan adalah teknik dan kualitas terjemahan. Teori pragmatik mengenai tindak tutur sebagai salah satu bagian yang penting dalam penelitian ini akan digunakan dalam menentukan karakteristik data yang nantinya dikaitkan dengan teknik dan dampaknya terhadap kualitas terjemahan. 


\section{Data dan Sumber Data}

Ada dua jenis data yang digunakan dalam penelitian ini yaitu;

1. Data Primer

Data yang termasuk kategori ini adalah artikel yang dipilih dan diambil dari koran 'The Jakarta Post' dan terjemahanya dalam bahasa Indonesia.

2. Data Sekunder

Data jenis ini ada dalam bentuk berbagai artikel pendukung yang memberikan informasi terkait tentang hal seputar artikel yang diambil sebagai sumber data dari koran 'The Jakarta Post'.

Sumber data yang lain adalah rater dan informan yang dilibatkan dalam penelitian ini guna memberikan penilaian dan pendapat mereka terkait kualitas terjemahan. Para rater/informan ini juga dimintai keterangan apabila penulis melakukan in-depth interview dengan informan mengenai hal-hal yang perlu diperjelas dari jawaban para informan terhadap kuesioner yang telah diberikan. Para rater/informan dipilih dari beberapa orang yang memiliki kualifikasi menguasai dan mampu berbahasa Inggris dan Indonesia dengan baik, terutama sekali mereka yang memiliki latar belakang pendidikan dan pengalaman di bidang penerjemahan.

\section{Validitas Data}

Untuk menjamin validitas dan reliabilitas data yang diperoleh dalam penelitian, maka data tersebut diteliti kembali dengan menggunakan teknik tianggulasi. Teknik trianggulasi merupakan pemeriksaan keabsahan data yang memaanfaatkan sesuatu yang lain di luar data untuk keperluan pengecekan atau pembanding terhadap data yang lain (Moleong, 2010: 330). Validasi data dalam penelitian ini menggunakan trianggulasi sumber data.

Triangulasi sumber data (triangulasi data) digunakan untuk memperoleh data yang valid dengan cara menggunakan beberapa sumber data yang berbeda. Trianggulasi sumber data dilakukan dengan cara membandingkan data primer yang diperoleh dari analisis dokumen yang berupa ujaran tindak tutur dari para tokoh dalam teks dengan hasil penilaian keakuratan dan keberterimaan dari para rater melalui kuesioner.

\section{Teknik Analisis Data}

Teknik analisis data yang digunakan dalam penelitian ini mengacu pada Content Analysis dari Spradley (1980). Dalam hal ini data akan dinalisis 
melalui sejumlah tahapan yaitu analisis domain, taksonomi, komponensial dan temuan/kesimpulan (yang mengandung pengetahuan nilai-nilai budaya).

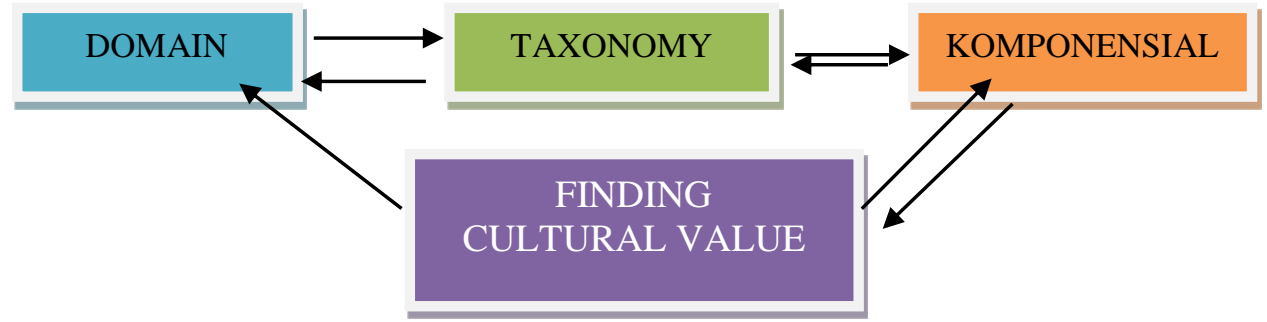

Gambar : Alur Analisis (Adapted from Spradely, 1980)

\section{Prosedur Penelitian}

Kegiatan penelitian ini melalui beberapa tahapan seperti diuraikan sebagai berikut:

1. Tahap Persiapan

Pada tahap ini, dikumpulkan sumber data dan referensi berkaitan dengan penelitian.

2. Tahap Pelaksanaan Penelitian

a. Membaca, memilih dan menyimak artikel pada koran 'The Jakarta Post'

b. Menerjemahkan artikel yang telah dipilih dari koran 'The Jakarta Post'

c. Melakukan pengumpulan dan analisis data sesuai tahapan teori Spradley.

d. Mengidentifikasi teknik penerjemahan yang digunakan

e. Melakukan pengkodean dan klasifikasi data

f. Memberikan kuesioner kepada rater terkait kualitas terjemahan

g. Mengolah dan menganalisis hasil kuesioner

h. Menarik simpulan

\section{HASIL DAN PEMBAHASAN}

Hasil penelitian ini meliputi kategori teknik penerjemahan yang digunakan, kualitas keakuratan dan keberterimaan hasil terjemahan, dan hubungan kualitas hasil terjemahan dengan kompetensi penerjemahan para mahasiswa. 


\section{Teknik penerjemahan yang digunakan}

Berdasarkan teknik penerjemahan yang digunakan dalam menerjemahkan teks dari artikel koran harian berbahasa Inggris ditemukan bahwa teknik penerjemahan yang digunakan untuk menerjemahkan total 105 data terbagi menjadi beberapa jenis sebagaimana terlihat di bawah ini.

Teknik penerjemahan tunggal paling banyak digunakan, sejumlah 68 data atau 64. 76\%. Selanjutnya teknik penerjemahan kuplet cukup banyak digunakan sejumlah 29 data atau 27.62\%. Sementara itu, teknik penerjemahan triplet jarang digunakan, hanya sejumlah 6 data atau 5.72\%. Terakhir, teknik penerjemahan kuplet paling sedikit digunakan yaitu sejumlah 2 data atau $1.90 \%$. Secara rinci data yang tergabung dalam masingmasing teknik ini bisa dilihat dalam uraian berikut.

\section{a. Teknik penerjemahan tunggal}

Teknik penerjemahan tunggal adalah penerapan satu teknik penerjemahan saja dalam penerjemahan satu data tuturan. Teknik penerjemahan tunggal paling banyak digunakan sejumlah 68 data atau 64.76\%. Teknik yang digunakan meliputi teknik Harfiah, Adaptasi, Peminjaman, Amplifikasi, Kesepadanan Lazim, Generalisasi, Adaptasi, Penambahan dan Penghilangan. Contoh :

BSU : Jokowi and his family will perform their Idul Fitri requests to God at Baitur Rahman mosque, in Banda Aceh.

- Harfiah

BSA : Jokowi dan keluarganya akan melakukan sholat Idul Fitri mereka di Baitur Rahman masjid, di Banda Aceh.

b. Teknik penerjemahan ganda/kuplet

Selain teknik penerjemahan tunggal, ditemukan pula penggunaan teknik penerjemahan ganda/teknik kuplet, yaitu perpaduan dua teknik penerjemahan yang diterapkan bersama dalam satu data tuturan menentukan padanan dalam teks bahasa sasaran. Teknik penerjemahan kuplet cukup banyak digunakan sejumlah 29 data atau $27.62 \%$. 
Contoh:

BSU : Tjahjo said regional leaders should follow the president's development plans closely.

- Modulation

BSA : Tjahjo mengatakan para pemimpin daerah harus - and harfiah mengikuti rencana pembangunan presiden lebih detail.

c. Teknik penerjemahan triplet

Selain bisa menerjemahkan dengan menggunakan dua teknik penerjemahan, seorang penerjemah juga bisa menerapkan penggabungan 3 teknik penerjemahan. Penggabungan 3 teknik penerjemahan ini dikenal dengan istilah teknik triplet. Teknik penerjemahan triplet jarang digunakan, hanya sejumlah 6 data atau $5.72 \%$.

Contoh:

BSU : A local community called Ketimbang Ngemis ( Instead of Begging) on social media platform Instagram is making the rounds on internet for its support of elderly residents who survive through poorly paid work.

- Literal,

- Deletion,

- Adaptation

BSA : Sebuah komunitas lokal bernama Ketimbang Ngemis pada media sosial Instagram sedang membuat rentetan dukungan di internet pada para lansia yang bertahan hidup melalui pekerjaan serabutan

d. Teknik penerjemahan lebih dari tiga teknik

Selain bisa menerjemahkan dengan menggunakan tiga teknik penerjemahan, ternyata di dalam data penelitian ini juga ditemukan penggunaan lebih dari tiga teknik penerjemahan. Teknik penerjemahan ini yang paling sedikit digunakan sejumlah 2 data atau $1.90 \%$.

Contoh:

BSU : He also expressed disappointment that several senior Indonesian journalists had recently visited Israel, after being invited by Netanyahu, who said that he wanted to change public opinion about Israel.

- Kesepadanan Lazim

- Borrowing (“opinion" to

BSA : Setelah diundang oleh Netanyahu, dia juga menyatakan kecewa bahwa baru-baru ini wartawan senior Indonesia be "opini”)

- Harfiah 
telah mengunjungi Israel, yang mengatakan bahwa - Modulation mereka ingin mengubah opini publik tentang Israel.

\section{Penilaian Kualitas Penerjemahan}

Penilaian kualitas terjemahan dalam penelitian ini didasarkan pada dua aspek, yaitu keakuratan dan keberterimaan. Penilaian kualitas terjemahan berdasarkan hasil dari analisa penulis (juga rater) dengan menggunakan kuesioner yang telah disiapkan.

Dari hasil penilaian (rater) didapat hasil penilaian kualitas terjemahan baik secara keakuratan maupun keberterimaan hasil terjemahan. Berikut ini akan diuraikan kualitas terjemahan data penelitian ini, baik dari segi tingkat keakuratan dan keberterimaan terjemahan.

\section{Penilaian Tingkat Keakuratan}

Terjemahan dikatakan akurat jika makna kata, istilah teknis, frasa, klausa atau kalimat bahasa sumber dialihkan secara akurat ke dalam bahasa sasaran; sama sekali tidak terjadi distorsi makna.

Terjemahan dikatakan kurang akurat bila sebagian besar makna kata, istilah teknis, frasa, klausa atau kalimat bahasa sumber dialihkan secara akurat ke dalam bahasa sasaran. Namun, masih terdapat distorsi makna atau terjemahan makna ganda (taksa) atau ada makna yang dihilangkan, yang mengganggu keutuhan pesan.

Terjemahan dinyatakan tidak akurat bila makna kata, istilah teknis, frasa, klausa atau kalimat bahasa sumber dialihkan secara tidak akurat ke dalam bahasa sasaran atau dihilangkan (deleted). 
Tabel 1 : Total Terjemahan Akurat, Kurang Akurat dan Tidak Akurat

\begin{tabular}{|c|l|c|c|}
\hline Nilai & \multicolumn{1}{|c|}{ Nomor Data } & Total & \% \\
\hline \multirow{3}{*}{ Akurat (3) } & $\begin{array}{c}6,8,10,16,17,18,19,21,22,25,26,30,32,33,34, \\
35,36,37,38,40,42,44,45,47,48,49,50,51,54, \\
55,56,59,61,62,63,64,65,67,68,69,70,72,73,\end{array}$ & & \\
& $74,75,76,77,78,80,81,82,84,88,93,94,95,96$, & 66 & $62.86 \%$ \\
\hline Kurang Akurat (2) & $\begin{array}{l}1,2,5,7,9,11,20,28,31,39,41,43,46,52,60,66, \\
71,79,83,85,90\end{array}$ & 21 & $20 \%$ \\
\hline Tidak Akurat (1) & $\begin{array}{l}3,4,12,13,14,15,23,24,27,29,53,57,58,86,87, \\
89,91,92,\end{array}$ & 18 & $17.14 \%$ \\
\hline \multicolumn{2}{|c|}{ JUMLAH } & $\mathbf{1 0 5}$ & $\mathbf{1 0 0} \%$ \\
\hline
\end{tabular}

Dari 105 data yang diteliti didapat 66 (62.86\%) data dengan terjemahan yang akurat, 21 (20\%) data diterjemahkan dengan kurang akurat, dan $18(17.14 \%)$ data diterjemahkan tidak akurat. Dari data yang masuk dalam kategori akurat, Kurang Akurat dan Tidak Akurat bisa dikatakan bahwa secara umum sebagian besar teks bahasa sumber diterjemahkan secara akurat. Namun ada beberapa teks yang diterjemahkan secara kurang akurat dan juga diterjemahkan secara tidak akurat dalam jumlah yang cukup signifikan juga.

\section{Penilaian Tingkat Keberterimaan}

Terjemahan dikatakan Berterima jika terjemahan terasa alamiah; istilah teknis yang digunakan lazim digunakan dan akrab bagi pembaca; frasa, klausa dan kalimat yang digunakan sudah sesuai dengan kaidah-kaidah bahasa Indonesia.

Terjemahan dikatakan Kurang Berterima bila Pada umumnya terjemahan sudah terasa alamiah; namun ada sedikit masalah pada penggunaan istilah teknis atau terjadi sedikit kesalahan gramatikal.

Terjemahan dinyatakan Tidak Berterima bila Terjemahan tidak alamiah atau terasa seperti karya terjemahan; istilah teknis yang digunakan tidak lazim digunakan dan tidak akrab bagi pembaca; frasa, klausa dan kalimat yang digunakan tidak sesuai dengan kaidah-kaidah bahasa Indonesia. 
Tabel 2 : Terjemahan Berterima, Kurang Berterima \& Tidak Berterima

\begin{tabular}{|c|c|c|c|}
\hline Nilai & Nomor Data & Total & $\%$ \\
\hline $\begin{array}{l}\text { Berterima } \\
\text { (3) }\end{array}$ & $\begin{array}{l}2,5,6,7,8,9,10,16,17,18,19,20,21,25,26, \\
30,32,33,34,35,36,37,38,40,41,42,43,44, \\
45,46,47,48,49,50,52,54,55,59,61,62,63, \\
64,65,67,68,69,70,72,73,74,75,76,77,78, \\
79,81,82,84,88,90,93,94,95,96,97,98,99, \\
100,101,102,103,104,105\end{array}$ & 73 & $69.52 \%$ \\
\hline $\begin{array}{c}\text { Kurang } \\
\text { Berterima (2) }\end{array}$ & $\begin{array}{l}1,4,11,12,14,15,22,28,31,39,51,56,60 \\
66,71,80,83,85,86,92\end{array}$ & 20 & $19.05 \%$ \\
\hline $\begin{array}{c}\text { Tidak Berterima } \\
\text { (1) }\end{array}$ & $3,13,23,24,27,29,53,57,58,87,89,91$ & 12 & $11.43 \%$ \\
\hline \multicolumn{2}{|r|}{ JUMLAH } & 105 & $100 \%$ \\
\hline
\end{tabular}

Dari 105 data yang diteliti didapat $73(69.52 \%)$ data dengan terjemahan yang Berterima, $20(19.05 \%)$ data diterjemahkan dengan Kurang Berterima, dan 12 (11.43\%) data diterjemahkan Tidak Berterima. Dari total terjemahan berterima, kurang berterima dan tidak berterima diatas, bisa diamati bahwa secara umum hampir $70 \%$ dari teks bahasa sumber diterjemahkan secara berterima. Sisanya kurang dari $20 \%$ diterjemahkan secara kurang berterima dan sedikitnya $11 \%$ yang diterjemahkan secara tidak berterima.

\section{KESIMPULAN}

Berdasarkan hasil penelitian dan pembahasan mengenai teknik penerjemahan yang digunakan dan kualitas hasil terjemahan artikel yang diambil dari koran harian berbahasa Inggris 'The Jakarta Post' dalam hal keakuratan (accuracy) dan keberterimaan (acceptability), diperoleh simpulan sebagai berikut: 
A. Penggunaan teknik penerjemahan

1. Penerjemahan Tunggal atau penerapan satu teknik penerjemahan saja dalam penerjemahan satu data tuturan sejumlah 68 data atau $64.76 \%$.

2. Penerjemahan Ganda/Kuplet, yaitu perpaduan dua teknik penerjemahan yang diterapkan bersama dalam satu data tuturan menentukan padanan dalam teks bahasa sasaran sejumlah 29 data atau $27.62 \%$.

3. Penerjemahan Triplet atau penggunaan/penggabungan 3 teknik penerjemahan sejumlah 6 data atau $5.72 \%$.

4. Penerjemahan lebih dari tiga teknik penerjemahan, sejumlah 2 data atau $1.90 \%$.

B. Kualitas terjemahan

Dari hasil penilaian tingkat keakuratan dan keberterimaan, diperoleh simpulan bahwa kemampuan/kompetensi penerjemahan mahasiswa cukup baik dengan berdasarkan data sebagai berikut:

1. Dari aspek keakuratan, dari 105 data yang diteliti didapat 66 $(62.86 \%)$ data dengan terjemahan yang akurat, 21 (20\%) data diterjemahkan dengan kurang akurat, dan 18 (17.14\%) data diterjemahkan tidak akurat.

2. Dari aspek keberterimaan, dari 105 data yang diteliti didapat 73 (69.52\%) data dengan terjemahan yang berterima, 20 (19.05\%) data diterjemahkan dengan kurang berterima, dan 12 (11.43\%) data diterjemahkan tidak berterima.

\section{SARAN}

Selanjutnya sebagai pertimbangan dan saran bagi penelitian selanjutnya, bisa penulis sampaikan beberapa hal. Pertama, penelitian ini masih terbatas dan didasarkan pada sumber teks dari artikel koran berbahasa Inggris "The Jakarta Post", mungkin bisa dikembangkan ke sumber teks berbeda lainya. Berikutnya, hasil atau temuan penelitian ini bisa dijadikan tolok ukur bagi capaian kompetensi penerjemahan para mahasiswa, sehingga bisa dijadikan pertimbangan untuk mengambil langkah-langkah teknis dalam perkuliahan untuk upaya peningkatan kompetensi penerjemahan para mahasiswa. 


\section{REFERENSI}

- $\quad$ Albir, Hutardo dan Molina, Lucia. (2002). Translation technigue Revised: A dynamic and functionalist approach.

- Baker, Mona. (1992). In other words: a course book on translation. London and New York ; Routledge.

- Dwiana Marcheni Arumningtyas (2013). Participle dalam judul The Jakarta Post. Universitas Gadjah Mada

- $\quad$ Echols, John M. \& Hassan Sadili. (1996). Kamus Indonesia Inggris (an Indonesian - Englishh dictionary). Jakarta: PT. Gramedia.

- $\quad$ Larson, Mildred. (1998). Meaning based translation: A guide to cross-language equivalence (second edition). Lanhan: University press of America.

- $\quad$ Miftakhur Rofi'ah (2014). Penggunaan pronomina di The Jakarta Post dan Jakarta Globe. Universitas Gadjah Mada

- $\quad$ Moleong, Lexy. (2010). Metode Penelitian Kualitatif (edisi revisi). Bandung: Rosda Karya.

- Nababan, M.R. (2010). Pengembangan model penilaian kualitas terjemahan. Ringkasan hasil penelitian HIKOM tahun II.

- $\quad$ Nida , E.A. \& Charles R Taber. (1982). The theory and practice of translation. Leiden E.J Brill.

- Novena (2015). Ambiguitas leksikal pada artikel The Jakarta Post: Kajian Semantis. repository.widyatama.ac.id

- $\quad$ Spradley, James. (2007). Metode Etnografi (edisi terjemahan bahasa indonesia oleh Misbah zulfa elizabeth). Yogyakarta: Tiara Wacana.

- $\quad$ Sutopo, H.B. (2002). Metodologi penelitian kualitatif: dasar teori dan terapannya dalam penelitian. Surakarta: UNS Press.

- Yohansyah (2011). Analisis sufiks -er dalam surat kabar The Jakarta Post: Satu kajian morfologis. repository.widyatama.ac.id 